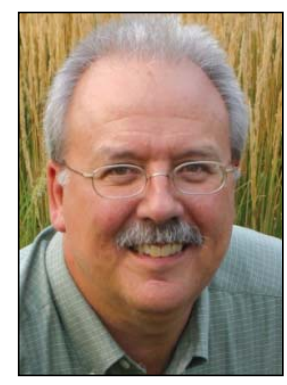

\author{
MetRICS FROM THE FIELD \\ Blending insights from research with insights from practice \\ Ken Meter
}

\title{
Two new tools for measuring economic impacts
}

Submitted May 11, 2015 / Published online June 3, 2015

Citation: Meter, K. (2015). Two new tools for measuring economic impacts.

Journal of Agriculture, Food Systems, and Community Development, 5(3), 5-7. http://dx.doi.org/10.5304/jafscd.2015.053.010

Copyright (C) 2015 by New Leaf Associates, Inc.

$\mathrm{T}$ wo new publications are appearing this year that should help shed new light on the ongoing discussion of how we measure the economic impacts of community-based foods initiatives. One offers critical insight, while the second is a very practical guide to compiling an economic case for local foods work. I've helped write both.

The critical analysis is an outgrowth of a column I wrote for this journal in January 2011 (Meter, 2011) in which I discussed economic multipliers. I argued that economic impact analyses

Ken Meter is one of the most experienced food system analysts in the U.S., integrating market analysis, business development, systems thinking, and social concerns. In addition to serving on the teams that produced the reports mentioned here, Meter is actively evaluating farm-to-school purchasing in South Carolina and Indiana, and continues to work with regions and state governments to assess food systems and the feasibility of proposed new food businesses and business clusters. often are not as useful as they are perceived to be, because the data used in calculating impacts is not as precise as users think it is. Moreover, I found that many local foods initiatives do not lend themselves to analysis through the industry standard software, IMPLAN, because local foods activity is relatively small in comparison with the scale of the databases that the software relies upon. While IMPLAN can be a powerful tool when used in the right manner, I argued that in their early stages for many community foods efforts, measuring the multiplier is not the best use of one's money. Rather, building new social and commercial linkages, and deepening established ones, within the community will help build the multiplier-which after all is one of the ultimate goals of community-based food activity. This might be a higher priority than generating a multiplier measurement.

My co-worker, Megan Phillips Goldenberg, had similar musings when she was in graduate school. She had begun to write a thesis on economic impact analysis. Ultimately she changed the 
focus of her formal paper, but postgraduation she was looking for a chance to return to this work. An opportunity arose for us to pursue this discussion thanks to the Centers for Disease Control and Prevention (CDC), which had allocated funds to the Illinois Public Health Institute (IPHI) to explore ways of measuring the economic and health impacts of institutional purchases of local foods.

Megan dusted off her files and set to work revisiting the literature. Her analysis was lucid. I wove in several insights from sources I knew as well as my own practical experiences. Our report, Critical Examination of Economic Impact Methodologies (Meter \& Goldenberg, 2015) appeared earlier this year. This is essentially a deeper dive into the material I addressed in my column, but rich with sources. Our work brings significant new insights. We propose that since the economic multiplier is a measure of community linkages, with the more highly linked communities achieving higher multipliers, it would be useful to measure the strength of social and commercial networks, especially in the early stages of local foods activity. We sketch out some ways in which these networks could be roughly quantified. It would not yield precise counts, but it seems likely to produce more useful and more honest information.

Our analysis seems to be congruent with the experience of many of our community partners. As part of the IPHI project, Megan and I also helped interview practitioners in five communities where institutions had purchased food from local farmers. They all said the core of their work was building strong, trusting relationships with community partners. These networks encompassed far more than commercial exchange. The connections they had forged helped build trust, allowed more creative responses to flourish (particularly in difficult times), and helped build a foundation of community support for all the partners involved (Lynch, Meter, Robles-Schrader, Goldenberg, Bassler,
Chusid, \& Jansen Austin, 2015). The five case studies in this report revealed unique dynamics in each of the diverse locales, which included San Diego, California; southwest Wisconsin; southern Arizona; Vermont; and Louisville, Kentucky.

The second recent publication is a practical guide for performing economic impact analysis. The USDA's Economic Impacts of Local and Regional Food Systems Toolkit is still under development, but you can find early materials at http://www.local foodeconomics.com. It will be released by its sponsor, the USDA Agricultural Marketing Service (AMS), later this year. In the process of developing this toolkit Megan and I were privileged to join a team that included some of the most seasoned practitioners in the nation.

The toolkit offers guidance on all the steps required to perform economic impact analysis, from framing a food assessment or economic impact study in its first stages, to compiling an overview of a given region by using publicly available data sets, to generating original data, to analyzing these findings and fashioning a narrative that inspires appropriate action. For those who want to dive deeply, the toolkit offers suggestions for how to work with a professional expert to perform an input/output analysis using software such as IMPLAN. The toolkit further shows how the basic IMPLAN approach may be refined in two significant ways: First, it can be modified to take into account opportunity costs— the fact that increased spending to buy locally produced food may take business away from existing suppliers who source food from a distance. Second, the toolkit outlines a method for inserting customized data sets into the software's databases in order to provide a more nuanced rendering of the local economy. Inserting such data is complex and requires considerable skill.

The drafting of the toolkit was coordinated by Dawn Thilmany McFadden of Colorado State University, working closely with AMS. The project 
advances a discussion that had been launched at a 2014 meeting convened by AMS along with the Union of Concerned Scientists and Michigan State University. We hope that future iterations of the toolkit will be made and that the process will help convene a community of practitioners who will refine these practices over time.

Drawing from the two publications, here are my thoughts on when IMPLAN is most useful:

- when estimating the impact of a revenue shift (in or out) that is significant in comparison with the regional economy that is being modeled. For example, Minnesota farmers currently sell about US $\$ 20$ billion of products per year; it would require a US $\$ 200$ million shift in sales to realize a $1 \%$ shift in cash receipts if one is modeling at the state level.;

- when modeling the impact of changes in established large firms or industries that are well represented by databases used in the IMPLAN software platform;

- when modeling the impact of one specific revenue shift over a time frame of a year or less, so that prevailing business networks are not substantially altered; and/or

- when solid data and expert professional help are available to insert tailored data sets into the databases provided by IMPLAN, in order to more closely reflect local commerce.

IMPLAN seems less useful in the following cases:

- when attempting to estimate the impact of a new small industry entering a very large economy-say, a US $\$ 250,000$ shift in sales in a multibillion dollar food system;

- when projecting the impacts of major changes (such as a proposed $20 \%$ shift in spending that is likely to require a change in infrastructure, or radically alter the patterns of commerce, so that conditions are no longer adequately represented by the databases provided by the modeling software);

- when projecting the impacts of long-term economic changes;

- in situations where conditions are rapidly changing, for example when there are a large number of new firms emerging that trade in local foods, or when prices are fluctuating; and/or

- when workers or natural resource inputs (such as available farmland or clean water) are not available to actually support the operation of a new business venture.

IMPLAN and other input/output software hold many uses in addition to calculating multipliers. I've seen them used well, and I've seen them used in questionable ways. Those who commission or perform such studies should enter the process with care. It is hoped that these two tools will offer useful insights to those who attempt to measure economic impacts.

\section{References}

Lynch, J., Meter, K., Robles-Schrader, G., Goldenberg, M. P., Bassler, E., Chusid, S., \& Jansen Austin, C. (Eds.). (2015). Exploring economic and health impacts of local food procurement. Chicago: Illinois Public Health Institute. Retrieved from http://www.crcworks.org/EHimpacts.pdf

Meter, K. (2011). Learning how to multiply. Journal of Agriculture, Food Systems, and Community Development, 1(2), 9-12. http://dx.doi.org/10.5304/jafscd.2010.012.014

Meter, K., \& Goldenberg, M. P. (2015, April). Critical analysis of economic impact methodologies. In J. Lynch, K. Meter, G. Robles-Schrader, M. P. Goldenberg, E. Bassler, S. Chusid, \& C. Jansen Austin (Eds.), Exploring economic and health impacts of local food procurement (pp. 111-124). Chicago: Illinois Public Health Institute. Retrieved from http://www.crcworks.org/econimpacts.pdf

U.S. Department of Agriculture Agricultural Marketing Service [AMS]. (2015). Economic impacts of local and regional food systems toolkit. Early materials are available at http://www.localfoodeconomics.com 